\title{
CORRIGENDUM
}

\section{Mutations in the known genes are not the major cause of MED; distinctive phenotypic entities among patients with no identified mutations}

Eveliina Jakkula, Outi Mäkitie, Malwina Czarny-Ratajczak, Gail C Jackson, Rita Damignani, Miki Susic, Michael D Briggs, William G Cole and Leena Ala-Kokko

European Journal of Human Genetics (2005) 13, 1166. doi:10.1038/sj.ejhg.5201472

Correction to: European Journal of Human Genetics (2005)

13, 292-301. doi:10.1038/sj.ejhg.5201314

The author name Malwina Czarny-Ratajczak was spelled incorrectly in the above-mentioned article; the correct spelling is now shown. 